Supporting Information

\title{
Signal-Enhanced Detection of Multiplexed Cardiac Biomarkers by a Paper-Based Fluorogenic Immunodevice Integrated with Zinc Oxide Nanowires
}

Xueying Guo, ${ }^{\dagger}$ Lijun Zong, ${ }^{\dagger}$ Yucui Jiao,${ }^{\dagger}$ Yufeng Han,${ }^{\dagger}$ Xiaopan Zhang,,${ }^{\dagger}$ Jia Xu,${ }^{\dagger}$ Lin $\mathrm{Li},{ }^{\dagger}$ Cheng-wu Zhang, ${ }^{\dagger}$ Zhipeng Liu, ${ }^{\dagger}$ Qiang Ju, Jinhua Liu, ${ }^{, \dagger}$ Zhihui Xu, ${ }^{*}$, Hai-Dong Yu, ${ }^{*}, \dagger,+$ and Wei Huang ${ }^{*}, \dagger,+$

Institute of Advanced Materials (IAM) \& Key Laboratory of Flexible Electronics (KLOFE), Jiangsu National Synergetic Innovation Center for Advanced Materials (SICAM), Nanjing Tech University (NanjingTech), 30 South Puzhu Road, Nanjing 211816, PR China

$¥ X i$ an Institute of Flexible Electronics, Northwestern Polytechnical University, 127 West Youyi Road, Xi'an 710072, PR China

$\S$ Department of Cardiology, The First Affiliated Hospital of Nanjing Medical University, 300 Guangzhou Road, Nanjing 210029, PR China

E-mail: iamhdyu@njtech.edu.cn; iamjhliu@njtech.edu.cn; wx-xzm@163.com; iamwhuang@njtech.edu.cn 


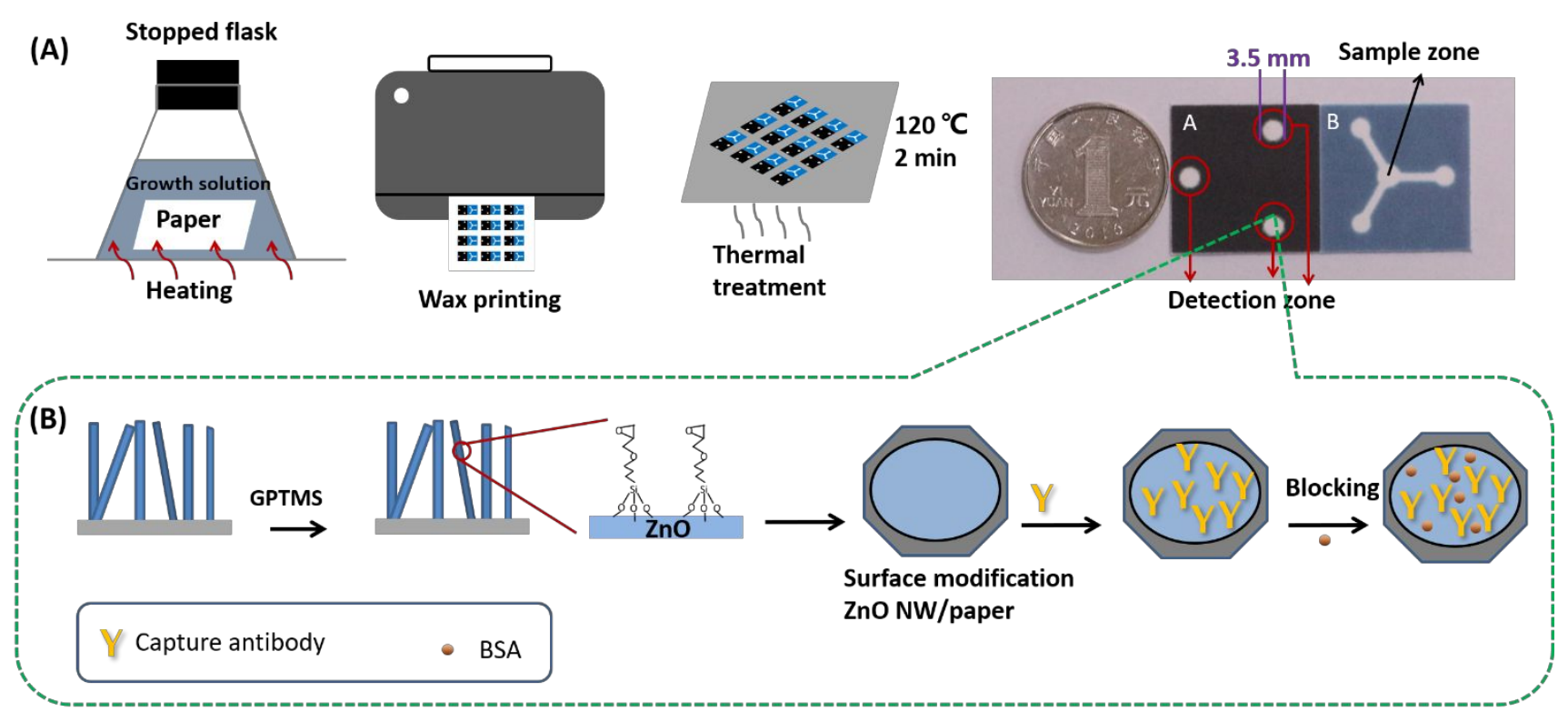

Figure S1. (A) Schematic showing the experimental setup for preparing $\mathrm{ZnO} \mathrm{NW} /$ paper, which simply consists of a stopped flask, a wax printer, and an oven. (B) Schematic showing the fabrication process of paper-based fluorogenic immunodevice. 

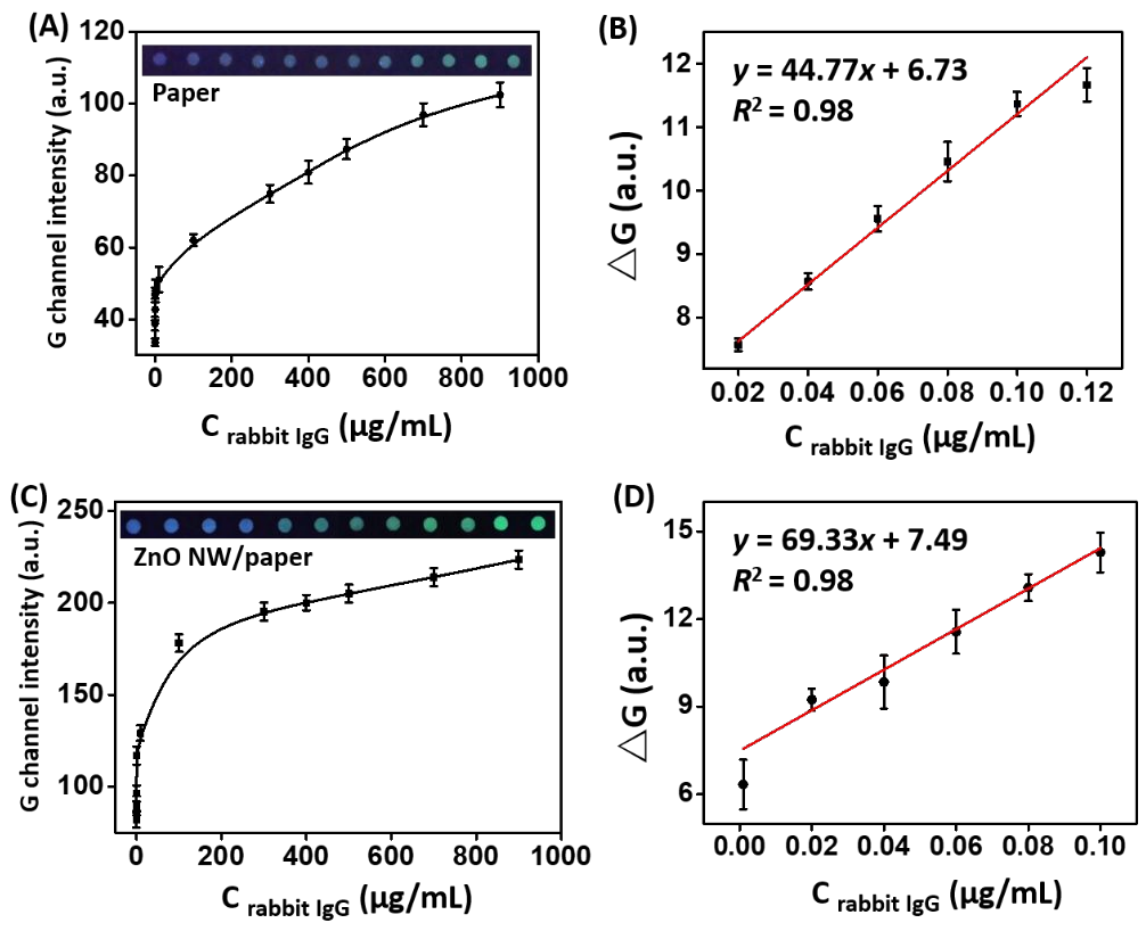

Figure S2. Paper-based detection of rabbit IgG. The calibration curves plotting green $(\mathrm{G})$ channel intensity of the detection zones against different concentrations of rabbit IgG on (A) paper and (C) ZnO NW/paper (Inset: representative fluorescence images). The concentrations of rabbit IgG in incubation buffer were $0,0.001,0.01$, $0.1,1,10,100,300,400,500,700$, and $900 \mu \mathrm{g} / \mathrm{mL}$ (from left to right). The linear relationship between $\mathrm{G}$ channel intensity and the concentration of rabbit IgG: (B) $0.02 \mu \mathrm{g} / \mathrm{mL}$ to $0.12 \mu \mathrm{g} / \mathrm{mL}$ on paper and (D) 0.001 $\mu \mathrm{g} / \mathrm{mL}$ to $0.1 \mu \mathrm{g} / \mathrm{mL}$ on $\mathrm{ZnO} \mathrm{NW} /$ paper. Data points for each concentration are the mean of seven replicates and the background of the paper has been subtracted. Error bars indicate one standard deviation.

Detection of rabbit IgG. Rabbit IgG was selected as a model for feasibility study of $\mathrm{ZnO} \mathrm{NW} /$ paper for biomedical testing. First, $0,0.001,0.01,0.1,1,10,100,300,400,500,700$, and $900 \mu \mathrm{g} / \mathrm{mL}$ rabbit IgG was covalently bound to the GPTMS-modified ZnO NW/paper for $30 \mathrm{~min}$. Unoccupied sites were blocked using blocking buffer $(0.05 \%$ Tween-20 and 1\% BSA in PBS) to prevent nonspecific adsorption of proteins for 10 min. Then, $2.5 \mu \mathrm{L}$ of $1 \mathrm{mg} / \mathrm{mL}$ FITC-labeled goat anti-rabbit IgG was added to each detection zone for $1 \mathrm{~min}$. After that, each detection zone was washed for three times by adding $10 \mu \mathrm{L}$ of phosphate buffer saline solution containing $0.05 \%$ Tween-20 (PBST) to the zone and placing blotting paper under the device to absorb the excess solution. Finally, the paper-based devices were placed in a self-made chamber using a battery-powered UV lamp for excitation and a smartphone for capturing the fluorescence images. 

Feasibility study of $\mathrm{ZnO} \mathrm{NW} /$ paper for biomedical testing. We have selected rabbit IgG as a model antigen for initial experiments. Calibration curves were constructed for detection of IgG on paper and $\mathrm{ZnO} \mathrm{NW} /$ paper with its concentration over the range from 0 to $900 \mu \mathrm{g} / \mathrm{mL}$ (Figures S2A and C). It was observed that the fluorescence intensity of the detection zone on $\mathrm{ZnO} \mathrm{NW} /$ paper is higher than that on paper for the same concentration of $\mathrm{IgG}$, which further validates the capability of $\mathrm{ZnO} \mathrm{NWs}$ for signal enhancement. The fluorescence intensity of the detection zone increased with increasing concentration of IgG. The fluorescence intensity increased linearly with increasing concentration of $\mathrm{IgG}$ over the range of $0.02-0.12 \mu \mathrm{g} / \mathrm{mL}$ for detection of $\mathrm{IgG}$ on paper (Figure S2B). The linear regression equation was $y=44.77 x+6.73\left(R^{2}=0.98\right)$, where $y$ is the green channel intensity value with the blank control subtracted and $x$ is the concentration of IgG. The detection limit of IgG on paper was calculated to be $1 \mathrm{ng} / \mathrm{mL}^{1}{ }^{1}$ The calibration curve of $\operatorname{IgG}$ on $\mathrm{ZnO}$ $\mathrm{NW} /$ paper was found to be linear over the range of $0.001-0.1 \mu \mathrm{g} / \mathrm{mL}$ (Figure S2D). The linear regression equation was $y=69.33 x+7.49\left(R^{2}=0.96\right)$. The detection limit of IgG on $\mathrm{ZnO} \mathrm{NW} /$ paper was calculated to be $0.1 \mathrm{ng} / \mathrm{mL}$. The detection limit of IgG was significantly enhanced by ZnO NWs ( $\sim 10$-fold compared to that on pure paper). The results showed that paper-based devices integrated with $\mathrm{ZnO}$ NWs enable highly sensitive detection for biomedical testing. 

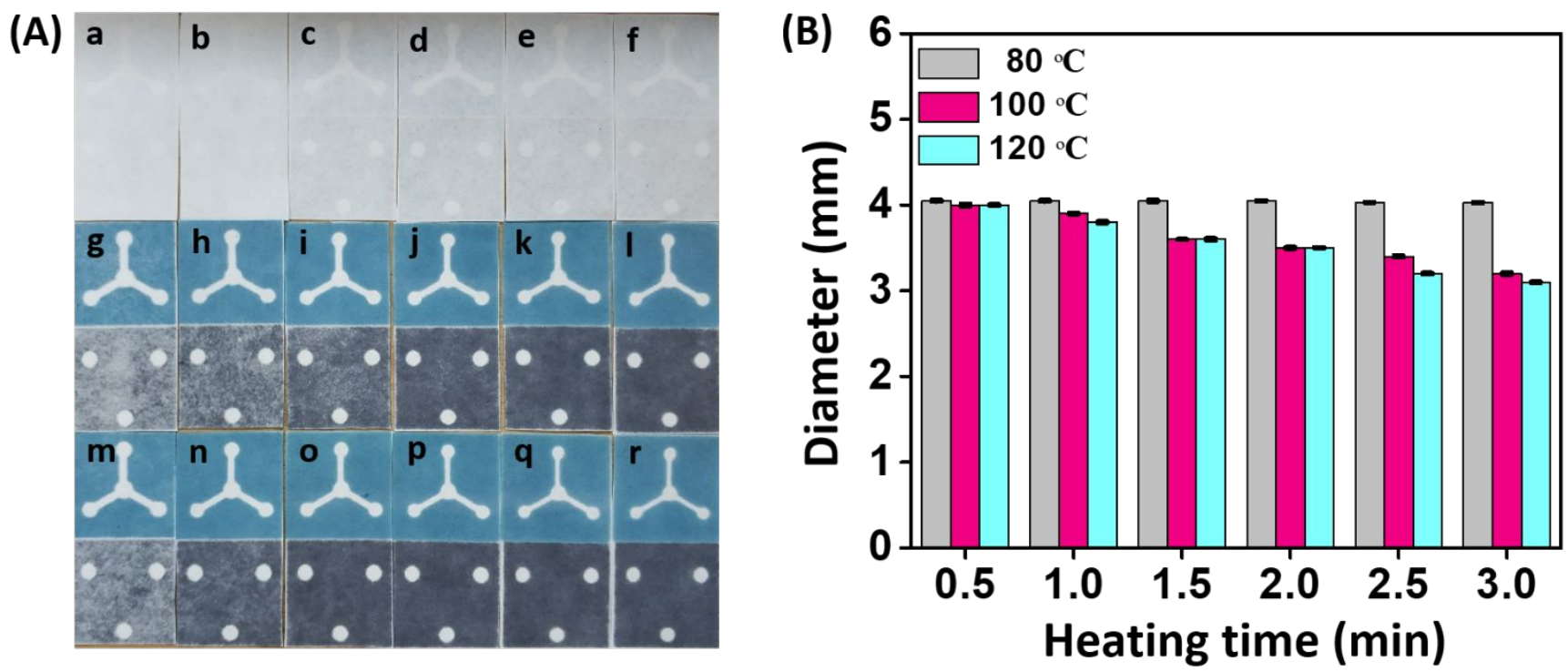

Figure S3. (A) Digital photographs of the back surface of paper-based devices prepared at different wax heating temperatures and time. The paper-based devices were printed using a wax printer and heated at (a-f) $80{ }^{\circ} \mathrm{C}$, (g-i) $100{ }^{\circ} \mathrm{C}$, and (m-r) $120^{\circ} \mathrm{C}$. In each panel, the heating time varied from (a, g, m) $0.5 \mathrm{~min},(\mathrm{~b}, \mathrm{~h}, \mathrm{n})$ $1 \mathrm{~min},(\mathrm{c}, \mathrm{I}, \mathrm{o}) 1.5 \mathrm{~min},(\mathrm{~d}, \mathrm{j}, \mathrm{p}) 2 \mathrm{~min},(\mathrm{e}, \mathrm{k}, \mathrm{q}) 2.5 \mathrm{~min}$, to (f, i, r) $3 \mathrm{~min}$. (B) The average diameter of the detection zones when heated at $80{ }^{\circ} \mathrm{C}, 100{ }^{\circ} \mathrm{C}$, and $120^{\circ} \mathrm{C}$ for different time $(\mathrm{n}=7)$.

For fabrication of paper-based devices, the wax heating temperature and time were optimized. After printing the pattern using the wax printer, the $\mathrm{ZnO} N W /$ paper was placed on an oven at $80{ }^{\circ} \mathrm{C}, 100{ }^{\circ} \mathrm{C}$, and $120{ }^{\circ} \mathrm{C}$ for different heating time (0.5 $\mathrm{min}, 1.0 \mathrm{~min}, 1.5 \mathrm{~min}, 2.0 \mathrm{~min}, 2.5 \mathrm{~min}$, and $3.0 \mathrm{~min}$ ). The wax could not fully penetrate the whole thickness of the $\mathrm{ZnO} \mathrm{NW} /$ paper at $80{ }^{\circ} \mathrm{C}$ (Figure S3A (a-f)) while the wax completely penetrated the entire $\mathrm{ZnO} \mathrm{NW} /$ paper over time at $100{ }^{\circ} \mathrm{C}$ and $120^{\circ} \mathrm{C}$ (Figure S3A (g-r)). For time saving, we chose $120{ }^{\circ} \mathrm{C}$ for $2 \mathrm{~min}$ as the optimized heating temperature and heating time. The average diameter of the detection zones was measured (Figure S3B). When heated at $120^{\circ} \mathrm{C}$ for $2 \mathrm{~min}$, the average diameter of the detection zones is $3.5 \mathrm{~mm}$. 

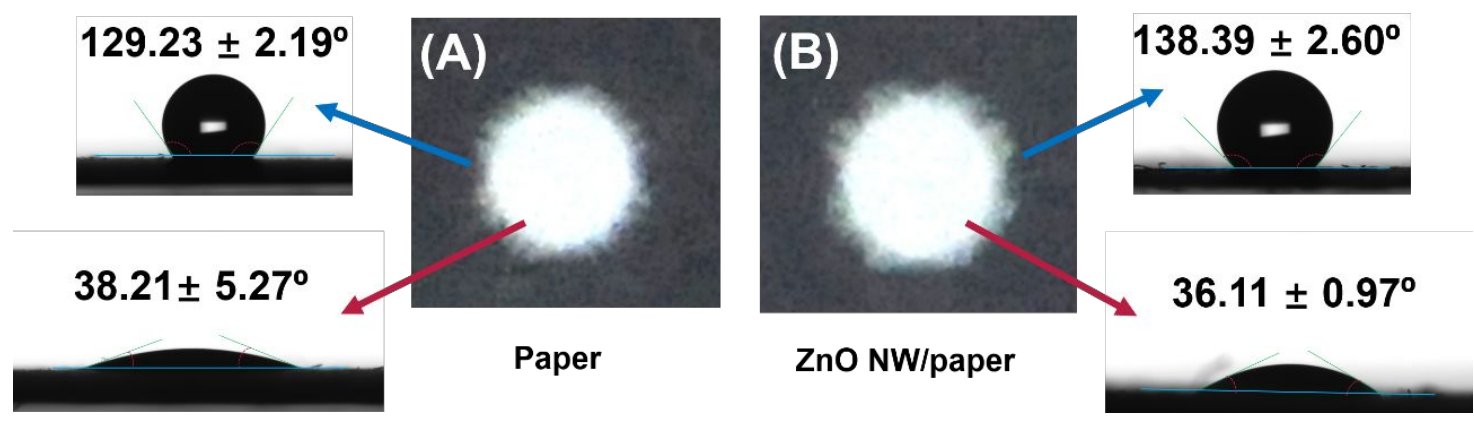

Figure S4. Contact angle measurement. The contact angle measurement with water of (A) the detection zone of pure paper and (B) the detection zone of $\mathrm{ZnO} \mathrm{NW} /$ paper. The blue arrow refers to contact angle of the waxed zone and the red arrow refers to contact angle of the unwaxed zone.

With the introduction of $\mathrm{ZnO}$ NWs, the wettability did not change much around the edges of the printed wax. As shown in Figure S4, the contact angles with water of waxed zones for pure paper and $\mathrm{ZnO} \mathrm{NW/paper} \mathrm{were}$ $129.23 \pm 2.19^{\circ}$ and $138.39 \pm 2.60^{\circ}$, respectively; the contact angles with water of unwaxed zones for pure paper and $\mathrm{ZnO} \mathrm{NW/paper} \mathrm{were} 38.21 \pm 5.27^{\circ}$ and $36.11 \pm 0.97^{\circ}$, respectively. The detection zones of the devices based on pure paper and $\mathrm{ZnO} \mathrm{NW/paper} \mathrm{both} \mathrm{show} \mathrm{non-smooth} \mathrm{edges} \mathrm{(Figure} \mathrm{S4),} \mathrm{probably} \mathrm{due} \mathrm{to}$ the relatively low quality of the wax barrier by wax printing. 
Table S1 Comparison of the time for distribution of $15 \mu \mathrm{L}$ of a solution of diluted red ink from sample zone to three detection zones on the devices based on pure paper and $\mathrm{ZnO} \mathrm{NW} /$ paper.

\begin{tabular}{cc}
\hline Type of paper-based devices & Time $(\mathrm{s})$ \\
\hline Pure paper & $10.5 \pm 0.7$ \\
ZnO NW/paper & $31.0 \pm 0.9$ \\
\hline
\end{tabular}

We have also tested the fluid flow rate using a solution of diluted red ink on the devices based on pure paper and $\mathrm{ZnO} \mathrm{NW} /$ paper. As shown in Table S1, the time that $15 \mu \mathrm{L}$ of the solution of diluted red ink was added to the sample zone and shunted to three detection zones were about $10.5 \mathrm{~s}$ and $31.0 \mathrm{~s}$ for pure paper and $\mathrm{ZnO}$ $\mathrm{NW/paper,} \mathrm{respectively.} \mathrm{The} \mathrm{reason} \mathrm{for} \mathrm{the} \mathrm{decrease} \mathrm{in} \mathrm{flow} \mathrm{rate} \mathrm{might} \mathrm{be} \mathrm{due} \mathrm{to} \mathrm{the} \mathrm{space} \mathrm{occupied} \mathrm{by} \mathrm{ZnO}$ NWs, which hindered the flow of the solution. With the introduction of $\mathrm{ZnO} \mathrm{NWs}$, the fluid flow rate became a little smaller, but the flow of the solution on the paper-based devices was still very rapid. 
(A)

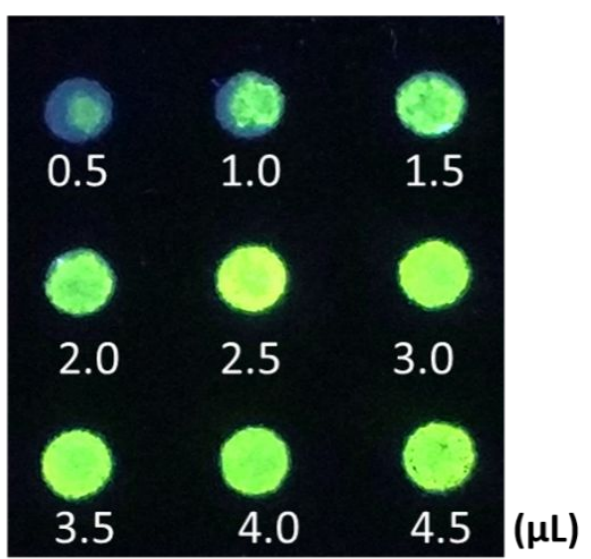

(B)

$2.5 \mu \mathrm{L}$

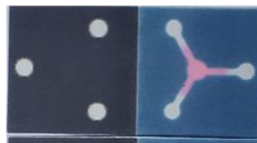

$5.0 \mu \mathrm{L}$

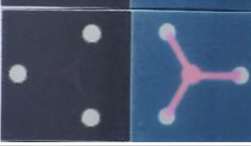

$7.5 \mu \mathrm{L}$

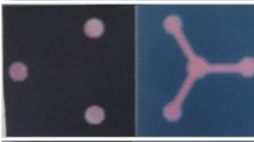

$10.0 \mu \mathrm{L}$

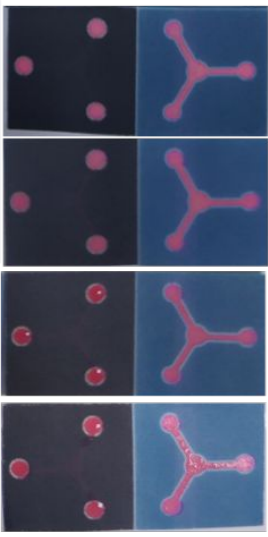

$15.0 \mu \mathrm{L}$

$17.5 \mu \mathrm{L}$

$20.0 \mu \mathrm{L}$

Figure S5. (A) Fluorescence images of the detection zones when adding $0.5 \mu \mathrm{L}, 1.0 \mu \mathrm{L}, 1.5 \mu \mathrm{L}, 2.0 \mu \mathrm{L}, 2.5$ $\mu \mathrm{L}, 3.0 \mu \mathrm{L}, 3.5 \mu \mathrm{L}, 4.0 \mu \mathrm{L}$, and $4.5 \mu \mathrm{L}$ of $25 \mu \mathrm{g} / \mathrm{mL}$ FITC-labeled IgG. (B) Digital photographs of the unfolded paper-based devices when $2.5 \mu \mathrm{L}, 5.0 \mu \mathrm{L}, 7.5 \mu \mathrm{L}, 10.0 \mu \mathrm{L}, 12.5 \mu \mathrm{L}, 15.0 \mu \mathrm{L}, 17.5 \mu \mathrm{L}$, and $20.0 \mu \mathrm{L}$ of diluted red ink were added into the sample zone of the folded paper-based devices, respectively.

Reducing the volumes of solutions added to the paper-based devices would decrease the analytical cost remarkably by reducing the consumption of reagents. But if the volume of the reagent is too small, the solution is insufficient to diffuse to the entire detection zone, resulting in a significant decrease of the detection signal. Hence, we have optimized the volumes of samples and antibodies added to the paper-based devices. The optimum volume of capture and FITC-labeled antibodies added to the detection zone was $2.5 \mu \mathrm{L}$ (Figure S5A), with the fluorescence image of uniformity and sufficiency obtained. In addition, diluted red ink was used to optimize the volume of samples added to the sample zone. Experimentally, layer B of the paper-based devices was folded over the layer $\mathrm{A}$, and $2.5 \mu \mathrm{L}, 5.0 \mu \mathrm{L}, 7.5 \mu \mathrm{L}, 10.0 \mu \mathrm{L}, 12.5 \mu \mathrm{L}, 15.0 \mu \mathrm{L}, 17.5 \mu \mathrm{L}$, and 20.0 $\mu \mathrm{L}$ of red ink were added to the sample zone on layer B. After the red ink shunted to three detection zones on layer A, the device was unfolded, the images of which were captured using a smartphone. The volume of samples added to the paper-based devices was optimized to be $15 \mu \mathrm{L}$ (Figure S5B). 


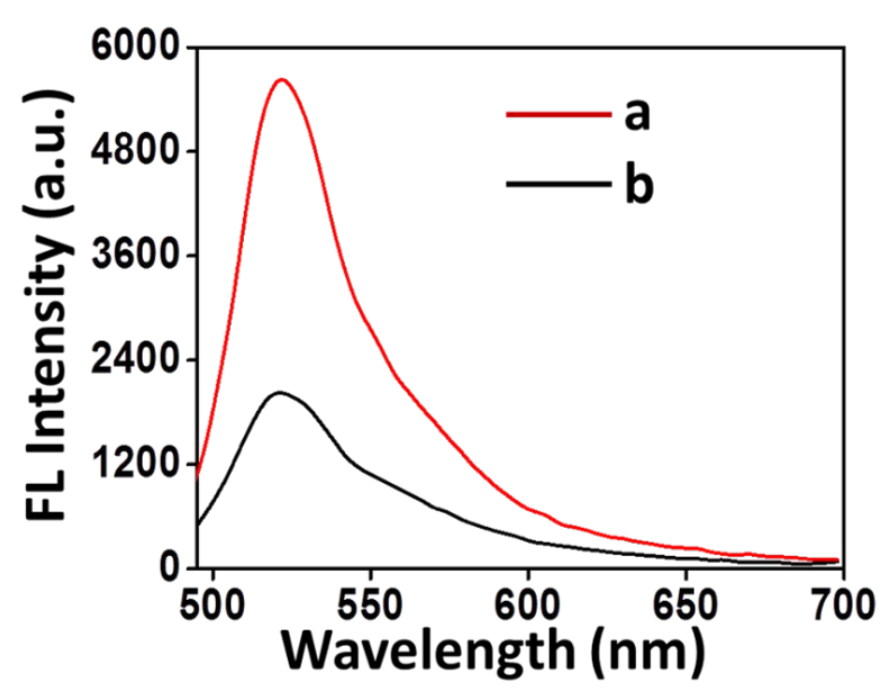

Figure S6. Fluorescence (FL) intensity of $2.5 \mu \mathrm{L}$ of $20 \mu \mathrm{g} / \mathrm{mL}$ FITC-labeled IgG on the detection zone of (a) GPTMS-modified ZnO NW/paper and (b) untreated $\mathrm{ZnO} \mathrm{NW} /$ paper.

To evaluate the immobilization of antibodies on $\mathrm{ZnO} \mathrm{NW} /$ paper after surface modification with (3glycidyloxypropyl)trimethoxysilane (GPTMS), $2.5 \mu \mathrm{L}$ of $20 \mu \mathrm{g} / \mathrm{mL}$ FITC-labeled IgG was added to the detection zone of untreated and GPTMS-modified ZnO NW/paper. After 30 min, $10 \mu \mathrm{L}$ of phosphate buffer saline solution containing $0.05 \%$ Tween-20 (PBST) was added to the detection zones to remove extra antibodies. It was observed that the fluorescence intensity of the detection zone on GPTMS-modified ZnO $\mathrm{NW}$ /paper was higher than that on untreated $\mathrm{ZnO} \mathrm{NW} /$ paper for the same concentration of FITC-labeled IgG (Figure S6), indicating that the amount of FITC-labeled IgG immobilized on the GPTMS-modified detection zone is greater than that on the unmodified zone. Therefore, the GPTMS-modified ZnO NW/paper has a higher capacity of antibody immobilization than the untreated. 


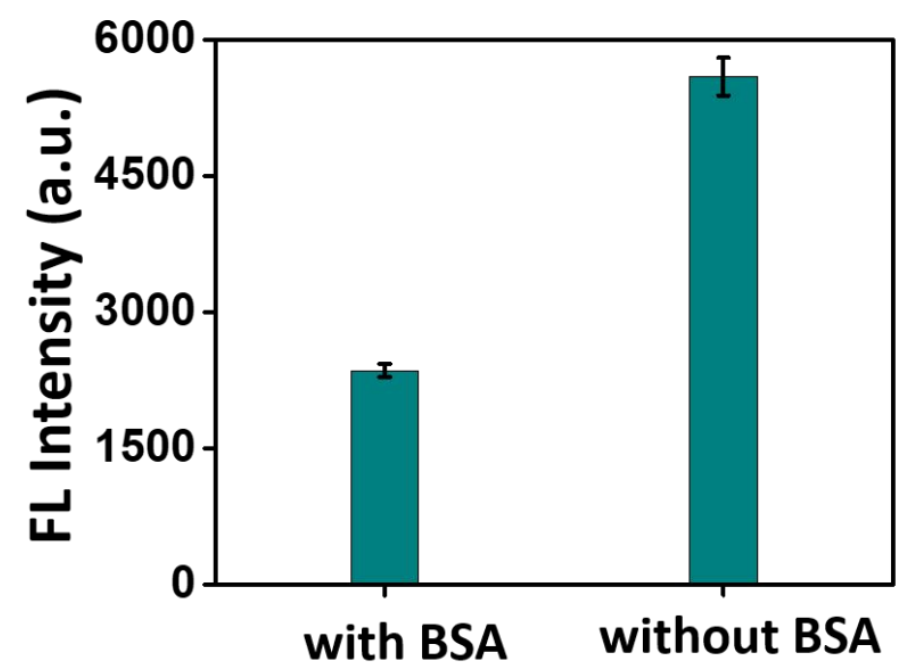

Figure S7. FL intensity of $2.5 \mu \mathrm{L}$ of $10 \mu \mathrm{g} / \mathrm{mL}$ of FITC-labeled IgG on the detection zone of GPTMSmodified $\mathrm{ZnO} \mathrm{NW/paper} \mathrm{with} \mathrm{and} \mathrm{without} \mathrm{BSA} \mathrm{treatment}(\mathrm{n}=7)$.

Bovine serum albumin (BSA) was used for eliminating the nonspecific binding of antigen and FITC-labeled antibody. Experimentally, $2.5 \mu \mathrm{L}$ phosphate buffer saline (PBS, $0.01 \mathrm{~mol} / \mathrm{L}, \mathrm{pH}=7.4$ ) and blocking buffer ( $0.05 \%$ Tween-20 and 1\% BSA in PBS) were added to two detection zones respectively. After 10 min, $2.5 \mu \mathrm{L}$ of $10 \mu \mathrm{g} / \mathrm{mL}$ FITC-labeled IgG was added to each detection zone. After $30 \mathrm{~min}$, each detection zone was washed for three times with $10 \mu \mathrm{L}$ PBST. The fluorescence intensity of the detection zone blocked by BSA was much lower than that without BSA treatment (Figure S7), suggesting that using BSA could block antibody adsorption on $\mathrm{ZnO} \mathrm{NW} /$ paper by more than $80 \%{ }^{2}$ 


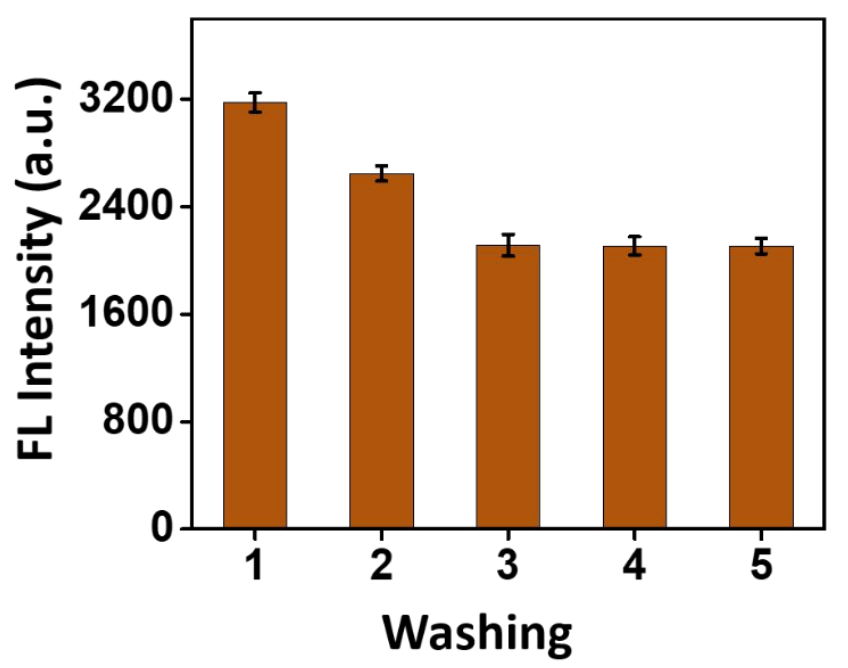

Figure S8. FL intensity of the detection zone when $2.5 \mu \mathrm{L}$ of $10 \mu \mathrm{g} / \mathrm{mL}$ FITC-labeled IgG was added, followed by washing for 1 time, 2 times, 3 times, 4 times, and 5 times $(n=7)$.

To optimize times of washing, $2.5 \mu \mathrm{L}$ of $10 \mu \mathrm{g} / \mathrm{mL}$ FITC-labeled IgG was added to the detection zones. Then, the zones were washed for 1 time, 2 times, 3 times, 4 times, and 5 times by using $10 \mu \mathrm{L}$ of PBST. Before 3 times of washing, the fluorescence intensity gradually decreased with increasing times of washing; after 3 times, the fluorescence intensity did not decrease much with increasing times of washing (Figure S8). Thus, we chose 3 times of washing. 

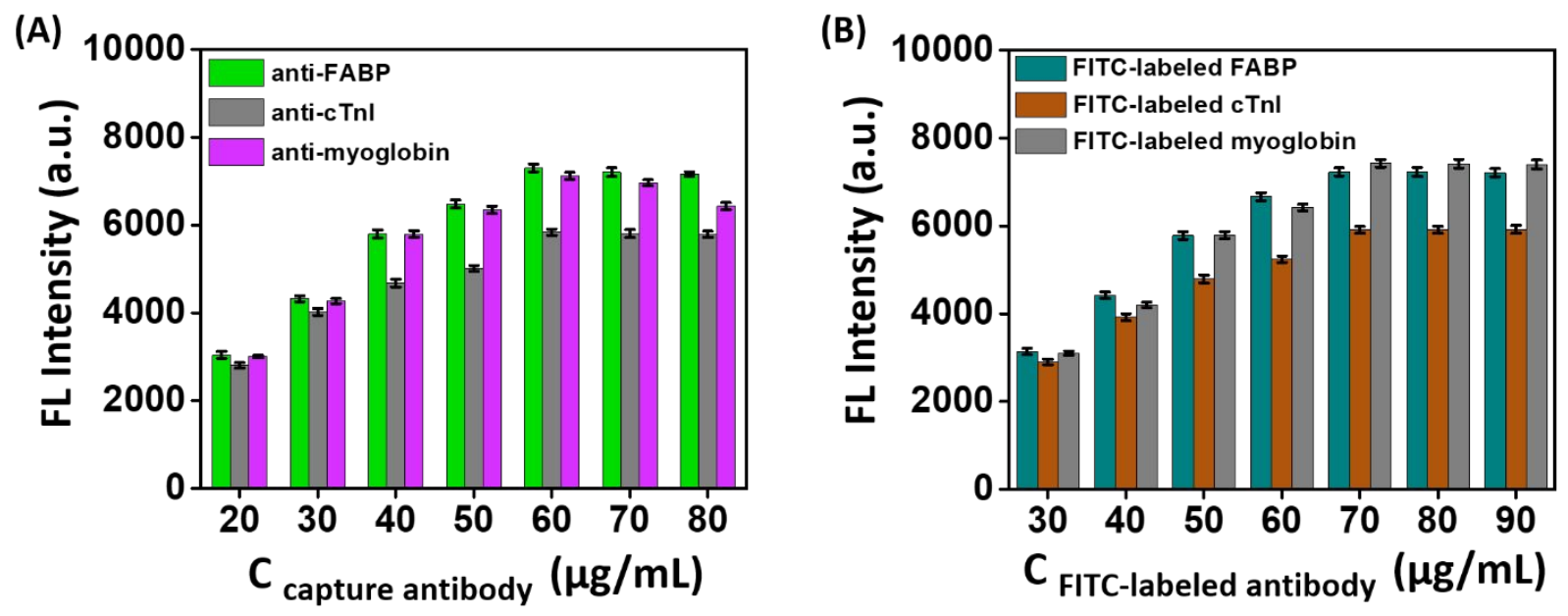

Figure S9. (A) FL intensity of the detection zones when $20 \mu \mathrm{g} / \mathrm{mL}, 30 \mu \mathrm{g} / \mathrm{mL}, 40 \mu \mathrm{g} / \mathrm{mL}, 50 \mu \mathrm{g} / \mathrm{mL}, 60 \mu \mathrm{g} / \mathrm{mL}$, $70 \mu \mathrm{g} / \mathrm{mL}$, and $80 \mu \mathrm{g} / \mathrm{mL}$ capture antibodies (i.e., anti-FABP, anti-cTnI, and anti-myoglobin) were added, respectively (n =7). (B) FL intensity of the detection zones when $30 \mu \mathrm{g} / \mathrm{mL}, 40 \mu \mathrm{g} / \mathrm{mL}, 50 \mu \mathrm{g} / \mathrm{mL}, 60 \mu \mathrm{g} / \mathrm{mL}$, $70 \mu \mathrm{g} / \mathrm{mL}, 80 \mu \mathrm{g} / \mathrm{mL}$, and $90 \mu \mathrm{g} / \mathrm{mL}$ FITC-labeled antibodies (i.e., anti-FABP, anti-cTnI, and anti-myoglobin) were added, respectively $(\mathrm{n}=7)$.

For optimizing the concentration of capture antibodies, $20 \mu \mathrm{g} / \mathrm{mL}, 30 \mu \mathrm{g} / \mathrm{mL}, 40 \mu \mathrm{g} / \mathrm{mL}, 50 \mu \mathrm{g} / \mathrm{mL}, 60 \mu \mathrm{g} / \mathrm{mL}$, $70 \mu \mathrm{g} / \mathrm{mL}$, and $80 \mu \mathrm{g} / \mathrm{mL}$ of three capture antibodies were added to the detection zones, with the concentrations of three cardiac biomarkers, FABP, cTnI, and myoglobin of $80 \mathrm{ng} / \mathrm{mL}$ and the concentrations of three FITClabeled antibodies of $80 \mu \mathrm{g} / \mathrm{mL}$. The fluorescence intensities for FABP, cTnI, and myoglobin initially increased with increasing concentration of capture antibodies, and reached their maximum values at $60 \mu \mathrm{g} / \mathrm{mL}$ (Figure S9A). So the optimum concentration of three capture antibodies was $60 \mu \mathrm{g} / \mathrm{mL}$. For optimizing the concentration of FITC-labeled antibodies, $60 \mu \mathrm{g} / \mathrm{mL}$ capture antibodies and $80 \mathrm{ng} / \mathrm{mL}$ cardiac biomarkers were added to the detection zones. Then, $30 \mu \mathrm{g} / \mathrm{mL}, 40 \mu \mathrm{g} / \mathrm{mL}, 50 \mu \mathrm{g} / \mathrm{mL}, 60 \mu \mathrm{g} / \mathrm{mL}, 70 \mu \mathrm{g} / \mathrm{mL}, 80 \mu \mathrm{g} / \mathrm{mL}$, and $90 \mu \mathrm{g} / \mathrm{mL}$ FITC-labeled antibodies were added to three corresponding detection zones. The fluorescence intensities for FABP, cTnI, and myoglobin initially increased with increasing concentration of FITC-labeled antibodies, and reached their maximum values at $80 \mu \mathrm{g} / \mathrm{mL}$ (Figure S9B). So the optimum concentration of three FITC-labeled antibodies was $80 \mu \mathrm{g} / \mathrm{mL}$. 


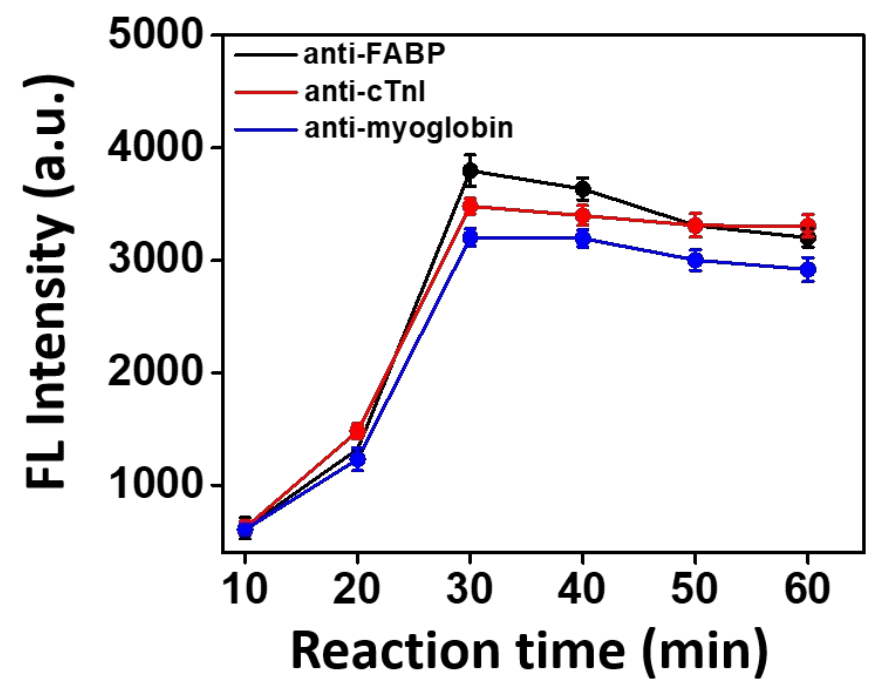

Figure S10. FL intensity of the detection zones when anti-FABP, anti-cTnI, and anti-myoglobin were added with reaction time of $10 \mathrm{~min}, 20 \mathrm{~min}, 30 \mathrm{~min}, 40 \mathrm{~min}, 50 \mathrm{~min}$, and $60 \mathrm{~min}$, respectively $(\mathrm{n}=7)$.

To optimize the reaction time for immobilizing capture antibodies, $2.5 \mu \mathrm{L}$ of $60 \mu \mathrm{g} / \mathrm{mL}$ capture antibodies for FABP, cTnI, and myoglobin were added on the detection zones with reaction time of $10 \mathrm{~min}, 20 \mathrm{~min}, 30 \mathrm{~min}$, $40 \mathrm{~min}, 50 \mathrm{~min}$, and $60 \mathrm{~min}$. With layer B folded over layer A, $15 \mu \mathrm{L}$ of the sample solution containing 20 ng/mL FABP, cTnI, and myoglobin was added to the sample zone. Then $2.5 \mu \mathrm{L}$ of $80 \mu \mathrm{g} / \mathrm{mL}$ FITC-labeled anti-FABP, FITC-labeled anti-cTnI, and FITC-labeled anti-myoglobin were added to the corresponding detection zones. The fluorescence intensities for FABP, cTnI, and myoglobin initially increased with increasing reaction time, and reached their maximum values at $30 \mathrm{~min}$ (Figure $\mathrm{S} 10$ ). So the optimum reaction time for immobilizing capture antibodies was $30 \mathrm{~min}$. 

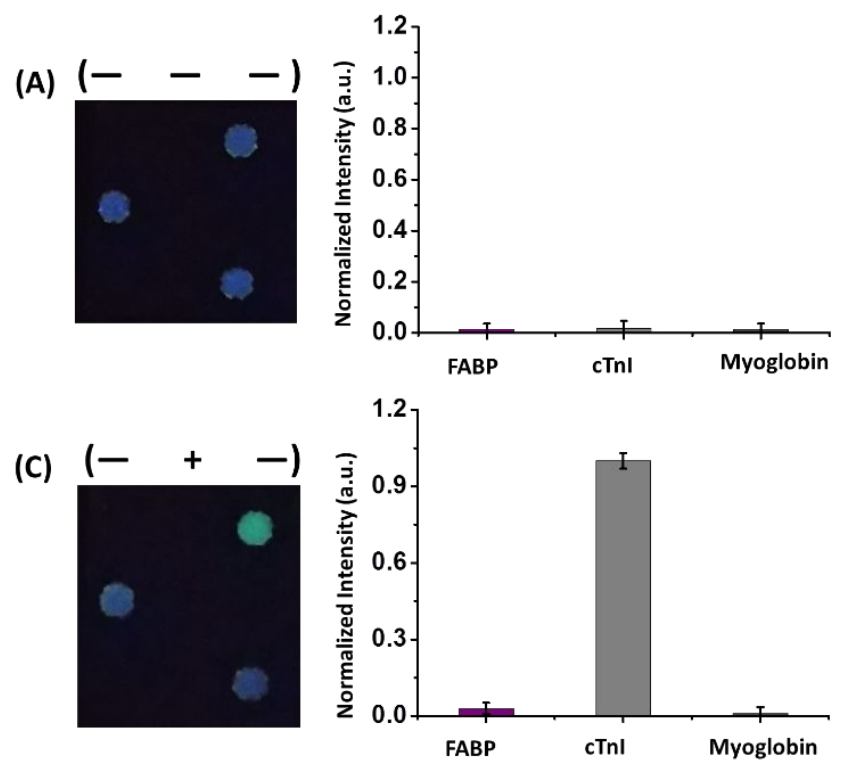

(E)
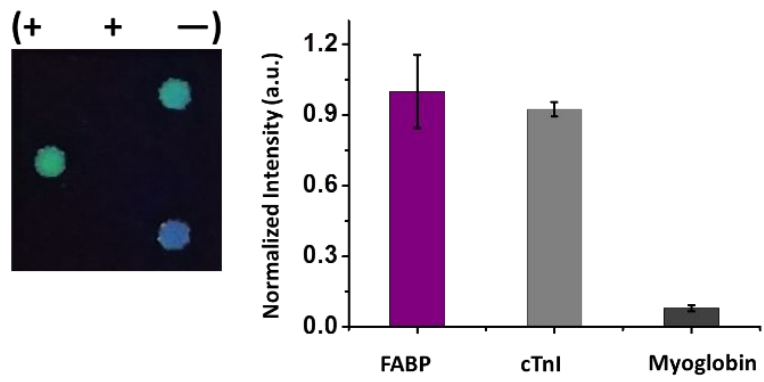

(G)
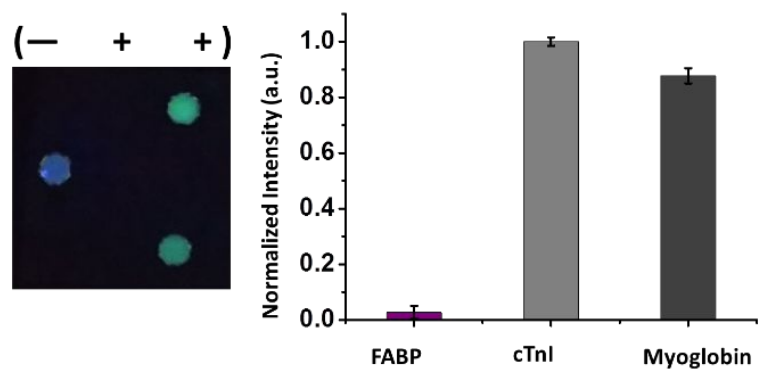

(B)
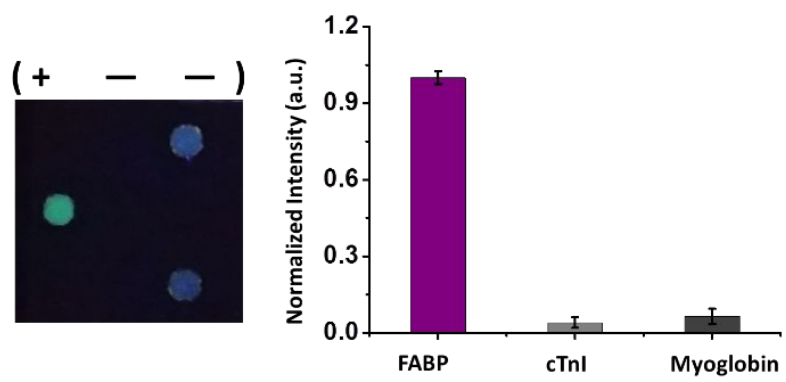

(D)
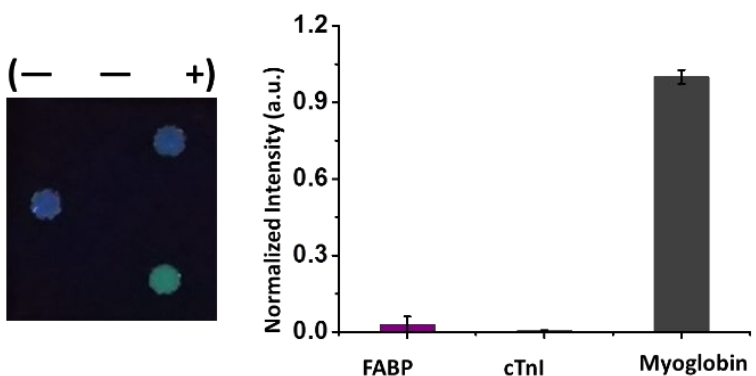

(F)
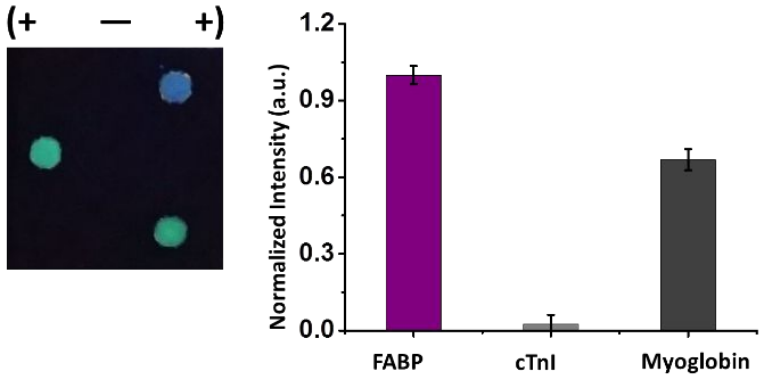

(H)
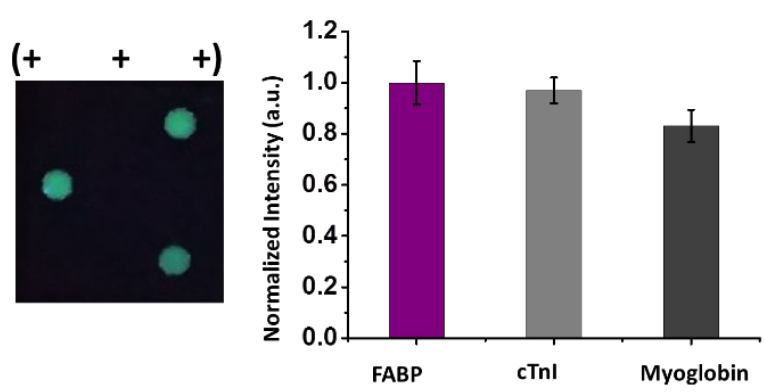

Figure S11. Multiplexed detection of three cardiac biomarkers using paper-based fluorogenic immunodevice integrated with $\mathrm{ZnO} \mathrm{NWs}$, FABP, cTnI, and myoglobin antigens in all possible combinations at final concentrations of $50 \mathrm{ng} / \mathrm{mL}$. Histograms represent the mean of seven replicates. Error bars indicate one standard deviation. 
(A) $\begin{array}{lllllllllll}0 & 5 & 10 & 20 & 30 & 40 & 50 & 60 & 70 & \mathrm{ng} / \mathrm{m}\end{array}$

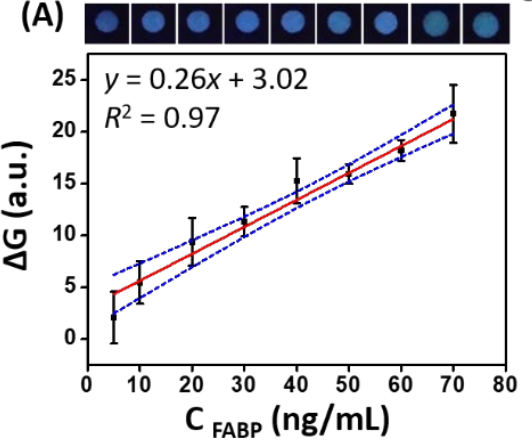

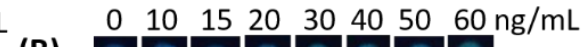

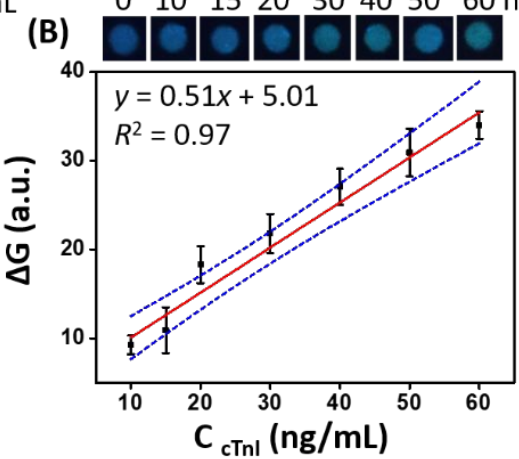

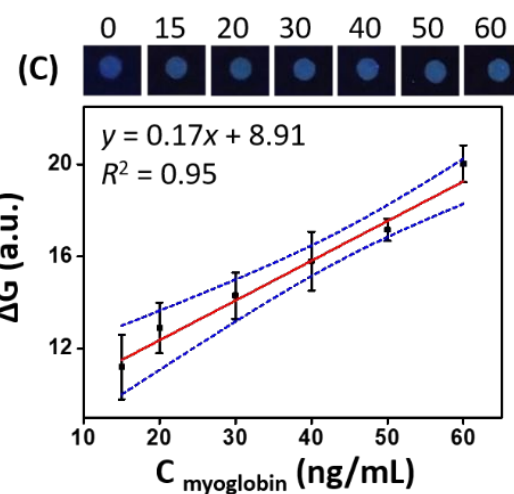

Figure S12. Quantitative detection of three cardiac biomarkers on pure paper: (A) FABP, (B) cTnI, and (C) myoglobin. The linear relationship between the $\mathrm{G}$ channel intensity and the concentrations of corresponding cardiac biomarkers. Data points for each concentration are the mean of seven replicates, and the background of the paper has been subtracted. Error bars indicate one standard deviation $(n=7)$, with 95\% (blue lines) confidence bands. 

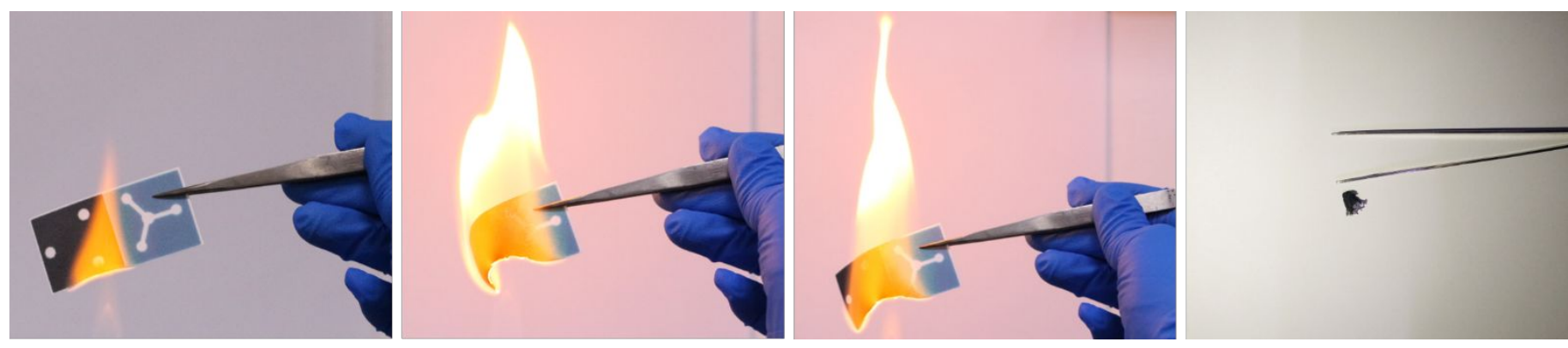

Figure S13. Digital photographs showing the disposal of paper-based fluorogenic immunodevice by incineration. The paper-based devices can be easily burned off, generating minimal amounts of solid waste. 
Table S2. Assay results in clinical samples by paper-based devices and commercialized ELISA kits.

\begin{tabular}{|c|c|c|c|c|c|c|}
\hline \multirow[t]{2}{*}{ Samples } & \multicolumn{2}{|c|}{ cTnI concentration (ng/mL) } & \multicolumn{2}{|c|}{ FABP concentration $(\mathrm{ng} / \mathrm{mL})$} & \multicolumn{2}{|c|}{ Myoglobin concentration $(\mathrm{ng} / \mathrm{mL})$} \\
\hline & $\begin{array}{l}\text { Measured } \pm \mathrm{SD} \\
(\mathrm{ng} / \mathrm{mL}) \text { paper }\end{array}$ & $\begin{array}{l}\text { Measured } \pm \text { SD } \\
(\mathrm{ng} / \mathrm{mL}) \text { ELISA }\end{array}$ & $\begin{array}{l}\text { Measured } \pm \mathrm{SD} \\
(\mathrm{ng} / \mathrm{mL}) \text { paper }\end{array}$ & $\begin{array}{l}\text { Measured } \pm \mathrm{SD} \\
(\mathrm{ng} / \mathrm{mL}) \text { ELISA }\end{array}$ & $\begin{array}{l}\text { Measured } \pm \mathrm{SD} \\
(\mathrm{ng} / \mathrm{mL}) \text { paper }\end{array}$ & $\begin{array}{l}\text { Measured } \pm \mathrm{SD} \\
(\mathrm{ng} / \mathrm{mL}) \text { ELISA }\end{array}$ \\
\hline 1 & $9.6 \pm 0.8$ & $10.6 \pm 0.7$ & $6.5 \pm 0.7$ & $7.1 \pm 0.5$ & $89.7 \pm 6.3$ & $94.7 \pm 5.8$ \\
\hline 2 & $8.2 \pm 0.9$ & $8.8 \pm 1.1$ & $9.8 \pm 0.8$ & $10.1 \pm 0.6$ & $74.3 \pm 13.8$ & $78.8 \pm 17.6$ \\
\hline 3 & $7.5 \pm 0.5$ & $9.1 \pm 0.4$ & $10.3 \pm 0.9$ & $10.5 \pm 0.6$ & $82.1 \pm 12.9$ & $80.4 \pm 17.3$ \\
\hline 4 & $8.7 \pm 1.1$ & $8.3 \pm 0.6$ & $10.3 \pm 0.9$ & $10.9 \pm 1.4$ & $70.5 \pm 5.9$ & $73.6 \pm 4.9$ \\
\hline 5 & $8.8 \pm 0.8$ & $9.5 \pm 0.9$ & $11.9 \pm 1.5$ & $13.5 \pm 1.2$ & $89.2 \pm 8.1$ & $84.4 \pm 7.7$ \\
\hline 6 & $8.3 \pm 0.5$ & $8.9 \pm 0.6$ & $8.9 \pm 0.9$ & $9.3 \pm 1.4$ & $60.9 \pm 6.1$ & $62.7 \pm 3.5$ \\
\hline 7 & $9.8 \pm 0.8$ & $10.1 \pm 0.7$ & $10.6 \pm 0.7$ & $11.2 \pm 1.5$ & $79.8 \pm 3.6$ & $73.1 \pm 4.7$ \\
\hline 8 & $9.7 \pm 0.8$ & $9.6 \pm 1.1$ & $8.9 \pm 0.7$ & $9.1 \pm 0.8$ & $59.3 \pm 5.7$ & $63.4 \pm 5.8$ \\
\hline 9 & $17.9 \pm 1.9$ & $18.5 \pm 2.6$ & $11.5 \pm 0.6$ & $11.2 \pm 0.9$ & $671 \pm 15.7$ & $630 \pm 12.9$ \\
\hline 10 & $42.5 \pm 5.2$ & $45.9 \pm 4.8$ & $10.7 \pm 1.2$ & $11.5 \pm 1.7$ & $1012.3 \pm 20.1$ & $1237.7 \pm 16.9$ \\
\hline 11 & $8.4 \pm 0.9$ & $8.8 \pm 0.7$ & $11.9 \pm 0.8$ & $12.4 \pm 2.1$ & $72.4 \pm 6.8$ & $77.9 \pm 7.5$ \\
\hline 12 & $24.2 \pm 1.6$ & $22.9 \pm 1.3$ & $12.1 \pm 1.0$ & $11.4 \pm 1.4$ & $14.8 \pm 2.2$ & $15.1 \pm 1.8$ \\
\hline 13 & $8.1 \pm 0.4$ & $9.2 \pm 0.6$ & $12.7 \pm 1.2$ & $12.4 \pm 0.9$ & $10.2 \pm 1.9$ & $10.8 \pm 1.3$ \\
\hline 14 & $9.1 \pm 0.7$ & $9.8 \pm 0.5$ & $10.3 \pm 1.3$ & $11.3 \pm 2.1$ & $6.9 \pm 0.6$ & $6.5 \pm 0.5$ \\
\hline 15 & $8.6 \pm 0.6$ & $8.5 \pm 0.5$ & $9.9 \pm 0.8$ & $10.1 \pm 1.0$ & $8.7 \pm 1.3$ & $9.8 \pm 1.2$ \\
\hline
\end{tabular}

SD: Standard deviation

Table S3. Comparison of various detection methods for determination of cardiac biomarkers reported in the literature.

\begin{tabular}{|c|c|c|c|c|c|c|}
\hline Method & Samples & Detection equipment & $\begin{array}{l}\text { Analytical } \\
\text { time }\end{array}$ & Limit detection & $\begin{array}{l}\text { Suitable for } \\
\text { multianlyte } \\
\text { detection }\end{array}$ & Reference \\
\hline Au film Dextran layer & cTnI & Andor CCD camera & $35 \mathrm{~min}$ & $1.4 \mathrm{ng} / \mathrm{mL}$ & Yes & Masson et al. ${ }^{3}$ \\
\hline HRP & $\mathrm{cTnI}$ & Photodiode detector & $20 \mathrm{~min}$ & $5.6 \mathrm{ng} / \mathrm{mL}$ & Yes & Torabi et al. ${ }^{4}$ \\
\hline HRP enzyme & $\mathrm{cTnI}$ & $\begin{array}{l}\text { CHI } 430 \mathrm{~A} \text { electrochemical } \\
\text { workstation }\end{array}$ & $1 \mathrm{~h}$ & $1 \mathrm{ng} / \mathrm{mL}$ & No & Ahammad et al..$^{5}$ \\
\hline Aptamer & cTnI & Spectrofluorophotometer & Over $1 \mathrm{~h}$ & $5 \mathrm{ng} / \mathrm{mL}$ & No & Dorraj et al. ${ }^{6}$ \\
\hline
\end{tabular}




\begin{tabular}{|c|c|c|c|c|c|c|}
\hline Au nanorod & cTnI & Spectrophotometer & $15 \mathrm{~min}$ & $10 \mathrm{ng} / \mathrm{mL}$ & No & Guo et al. ${ }^{7}$ \\
\hline Nanocomposite & cTnI & $\begin{array}{l}\text { wavelength modulation SPR } \\
\text { instrument }\end{array}$ & Over $40 \mathrm{~min}$ & $1.25 \mathrm{ng} / \mathrm{mL}$ & No & Wu et al. ${ }^{8}$ \\
\hline ZnO NW/paper & cTnI & Smartphone & $5 \mathrm{~min}$ & $1 \mathrm{ng} / \mathrm{mL}$ & Yes & This work \\
\hline
\end{tabular}




\section{References}

(1) Gong, X. Q.; Zhang, B.; Piao, J. F.; Zhao, Q.; Gao, W. C.; Peng, W. P.; Kang, Q.; Zhou, D. M.; Shu, G. M.; Chang, J. Nanomedicine 2018, 14, 1257-1266.

(2) Khan, M. S.; Pande, T.; van de Ven, T. G. M. Colloids Surf., B 2015, 132, 264-270.

(3) Masson, J. F.; Obando, L.; Beaudoin, S.; Booksh, K. Talanta 2004, 62, 865-870.

(4) Torabi, F.; Far, H. R. M.; Danielsson, B.; Khayyami, M. Biosens. Bioelectron. 2007, 22, 1218-1223.

(5) Ahammad, A. J. S.; Choi, Y. H.; Koh, K.; Kim, J. H.; Lee, J. J.; Lee, M. Int. J. Electrochem. Sci. 2011, 6, 1906-1916.

(6) Dorraj, G. S.; Rassaee, M. J.; Latifi, A. M.; Pishgoo, B.; Tavallaei, M. J. Biotechnol. 2015, 208, 80-86.

(7) Guo, Z. R.; Gu, C. R.; Fan, X.; Bian, Z. P.; Wu, H. F.; Yang, D.; Gu, N.; Zhang, J. N. Nanoscale Res. Lett. 2009, 4, 1428-1433.

(8) Wu, Q.; Sun, Y.; Zhang, D.; Li, S.; Zhang, Y.; Ma, P.; Yu, Y.; Wang, X.; Song, D. Biosens. Bioelectron. 2017, 96, 288-293. 